\title{
MODEL PENINGKATAN PERAN BANK KALBAR SEBAGAI LEMBAGA KEUANGAN DALAM PEMBANGUNAN KAWASAN PERBATASAN DI ERA DIGITAL
}

\author{
Ria Norsan \\ Universitas Tanjungpura, Pontianak \\ Email korespondensi : b3081201007@student.untan.ac.id
}

\begin{abstract}
Abstrak
$10.26418 /$ pipt.2021.2

Kawasan perbatasan antar negara memiliki arti strategis baik dari sudut pandang pertahanan dan keamanan maupun dari sudut pandang pertumbuhan ekonomi. Kawasan perbatasan antar negara di wilayah Provinsi Kalimantan barat pada umumnya masih berkategori kawasan tertinggal yang masih menghadapi berbagai permasalahan dari aspek fisik, sarana dan prasarana wilayah, sosial, ekonomi, serta politik sehingga kebutuhan pembiayaan pembangunan di kawasan tersebut sangat besar. Di sisi lain, perkembangan zaman yang ditandai dengan meluasnya penggunaan teknologi digital juga menjadi tantangan tersendiri dalam upaya mengejar ketertinggalan di kawasan perbatasan. Artikel ini bertujuan untuk mendeskripsikan model peningkatan peran yang perlu dilakukan oleh Bank Kalbar sebagai suatu lembaga keuangan dalam rangka mendukung pembangunan di kawasan perbatasan antar negara di wilayah Provinsi Kalimantan Barat. Data yang digunakan dalam penelitian bersumber dari dokumen-dokumen resmi terkait dengan pembangunan kawasan perbatasan, laporan-laporan, serta hasil penelitian terdahulu. Analisis data dilakukan secara kualitatif dengan metode triangulasi terhadap hasil penelaahan terhadap dokumen-dokumen terkait dan artikel penelitian dengan tema pembangunan perbatasan dan perbankan, serta hasil wawancara. Model peningkatan peran disusun dengan mengadopsi model Pengaruh Digitalisasi Perbankan terhadap kinerja keuangan bank (Mbama \& Ezepue, 2018). Terkait dengan peran Bank Kalbar dalam pembangunan wilayah khususnya perbatasan, maka ditambahkan aspek-aspek rebranding, perluasan fitur Digital Banking serta kerja sama dengan marketplace online.
\end{abstract}

Kata kunci: Pembangunan ekonomi, lembaga keuangan, rebranding

\section{PENDAHULUAN}

$\begin{array}{ccr}\text { Salah } & \text { satu karakteristik } & \text { wilayah } \\ \text { Provinsi } & \text { Kalimantan Barat adalah }\end{array}$
terdapatnya perbatasan antar negara yang membentang sepanjang $972,95 \mathrm{~km}$ di bagian utara provinsi ini, yang meliputi 5 Kabupaten, 14 Kecamatan dan 170 Desa/Kelurahan (BAPPEDA, 2021). Wilayah sepanjang garis perbatasan ini umumnya berada dalam kondisi ketertinggalan terutama jika dibandingkan dengan wilayah negara Malaysia di seberangnya. Berbagai permasalahan masih harus mendapatkan perhatian khusus di kawasan yang seharusnya menjadi gerbang depan negara ini. Di antaranya, penataan ruang dan pemanfaatan sumber daya alam, ketertinggalan wilayah, rendahnya sumber daya manusia, dan sebagainya (Kemitraan, 2011).
Kondisi ketertinggalan kawasan perbatasan selama ini dipandang sebagai buah dari pendekatan pembangunan yang mengutamakan pendekatan keamanan, sementara banyak potensi ekonomi di kawasan tersebut yang sebenarnya dapat dimanfaatkan untuk menunjang perekonomian daerah.

Berdasarkan data umum yang dipublikasikan oleh Badan Pengelola Perbatasan Daerah Provinsi Kalimantan Barat, kawasan perbatasan menyimpan potensi sumber daya alam di sektor pertambangan, kehutanan, perkebunan, perikanan, pertanian dan pariwisata (BPPD, 2021). Besarnya potensi ekonomi ini yang dibarengi dengan arus globalisasi dan dukungan kebijakan nasional memberikan peluang yang besar dalam percepatan pembangunan di wilayah tersebut (Hendri \& Hasanuddin, 2017), meskipun belum mampu 
untuk mengangkat taraf hidup masyarakat karena belum dikembangkan secara optimal.

Pengembangan potensi ekonomi tentunya tidak terlepas dari peran lembaga keuangan sebagai wahana yang mampu menghimpun dan menyalurkan dana masyarakat secara efektif dan efisien ke arah peningkatan taraf hidup rakyat (Wiwoho, 2014). Bank Kalbar sebagai Badan Usaha Milik Daerah tentunya sangat diharapkan dapat memainkan peran sentral dalam penyediaan jasa keuangan guna menunjang kegiatan ekonomi dan perdagangan di kawasan perbatasan, khususnya di era digitalisasi saat ini. Hal ini kiranya selaras dengan tema pelayanan yang diusung oleh Bank Kalbar pada tahun 2019 yaitu Berinovasi Menuju Era Digitalisasi Perbankan. Berangkat dari hal-hal yang dikemukakan di atas, tulisan ini bertujuan untuk mengeksplor model peningkatan peran Bank Kalbar sebagai lembaga keuangan dalam menunjang pembangunan kawasan perbatasan di era digital ini.

\section{METODOLOGI}

Tulisan ini disusun sebagai hasil penelitian dengan pendekatan kualitatif. Jenis penelitian ini adalah studi kasus (case study). Berdasarkan pendekatan yang dipilih, maka instrumen penelitian yang paling utama peneliti itu sendiri.

Untuk keperluan analisis, pengumpulan data dan informasi dilakukan melalui studi dokumentasi, observasi lapangan, dan teknik wawancara. Analisis data dilakukan dengan metode triangulasi yang melibatkan observasi, interview dan dokumentasi (YIN, 2006).

\section{HASIL DAN PEMBAHASAN}

\section{a. Arti Penting Kawasan perbatasan}

Dalam pembahasan tentang kawasan perbatasan, van Houtum (2005) mengemukakan terjadinya perubahan paradigma dari border menjadi boundary. Secara singkat dijelaskannya bahwa paradigma border pada tahun 1960-an lebih menekankan kepada evolusi dan perubahan pada garis teritorial perbatasan, sementara dalam studi kekinian lebih banyak membahas tentang tempat di mana terjadi perubahan sosio spasial. Dengan kata lain, studi perbatasan mempelajari tentang aktivitas manusia yang membentuk perubahan-perubahan di ruang perbatasan.

Berangkat dari pemahaman bahwa membahas perbatasan bukanlah sekedar mengenai garis batas teritorial namun menyangkut berbagai aspek kehidupan manusia yang luas, maka kawasan perbatasan dipandang memiliki arti yang sangat vital dan strategis. Koespramudyo dalam Sudiar (2015) menyebutkan tiga sudut pandang arti penting kawasan dimaksud, yaitu

1) Sudut pandang pertahanan-keamanan.

Sudut pandang ini kiranya berkaitan erat dengan paradigma lama sebagaimana dikatakan oleh Houtum di atas. Perbatasan dibahas sebagai garis batas teritorial yang berkaitan dengan penjagaan kedaulatan dan keamanan negara, terutama ancaman kejahatan transnasional seperti terorisme, human trafficking, narkoba dan sebagainya.

2) Sudut pandang ekonomi-perdagangan.

Kawasan ini dipandang sebagai titik tumbuh perekonomian nasional dan regional. Aktivitas perdagangan antar negara yang terjadi di kawasan ini berpotensi untuk mengembangkannya menjadi kawasan teknologi, kawasan pariwisata, kawasan agroindustri dan berbagai bentuk kawasan potensial lainnya. Hal ini berarti bahwa kawasan perbatasan dapat menjadi penggerak perekonomian daerah atau negara.

3) Sudut pandang sosial budaya.

Secara kultural, masyarakat di kawasan perbatasan antar negara umumnya memiliki kesamaan karakter sifat dan tradisi. Hal ini menyebabkan adanya interaksi yang bersifat langsung dan intensif, baik dalam hubungan sosialkultural yang terjadi secara tradisional maupun dalam kegiatan-kegiatan ekonomi yang lebih modern. 


\section{b. Kebijakan Pembangunan Perbatasan}

Di tingkat nasional, telah disusun sebuah Grand Design Pengelolaan Batas Negara dan Kawasan Perbatasan di Indonesia. Di dalam desain besar tersebut dikemukakan tujuan utama dari pengelolaan perbatasan, yaitu menjaga integrasi Negara Kesatuan Republik Indonesia, membangun kawasan perbatasan demi kesejahteraan rakyat, dan menguatkan kapasitas negara dalam persaingan global (BNPP, 2011).

Tujuan utama tersebut di atas merupakan bentuk adaptasi terhadap beberapa pendekatan dalam pembangunan perbatasan, yaitu pertama, Pendekatan Kesejahteraan dengan fokus pengembangan aktivitas ekonomi dan perdagangan demi meningkatkan kesejahteraan masyarakat di kawasan tersebut; Kedua, Pendekatan Keamanan melalui pengawasan yang ketat demi menjaga keamanan nasional, terutama dari pelanggaran kedaulatan. Ketiga, pendekatan lingkungan yang secara operasional merupakan langkah-langkah yang terukur dalam mengendalikan pemanfaatan ruang guna menjaga keberlangsungan lingkungan (Sudiar, 2015). Kebijakan pembangunan jangka panjang di tingkat nasional mengamanatkan pengembangan wilayah-wilayah perbatasan dengan arah kebijakan yang berorientasi keluar (outward-looking) dengan memanfaatkan kawasan perbatasan sebagai pintu gerbang kegiatan perdagangan dan ekonomi dengan negara-negara lainnya. Selain itu juga pendekatan kesejahteraan digunakan untuk mengentaskan masyarakat perbatasan dari kondisi ketertinggalan.

Di dalam RPJMN Tahun 2020-2024, pembangunan kawasan perbatasan diarahkan dalam rangka mengembangkan Wilayah untuk Mengurangi Kesenjangan dan Menjamin Pemerataan. Secara khusus, agenda pembangunan kewilayahan di Pulau Kalimantan dalam RPJMN memberikan perhatian terhadap belum optimalnya peran kawasan perbatasan dalam pembangunan wilayah, sehingga dimasukkan sebagai salah satu sasaran prioritas dalam pembangunan kewilayahan.

Di tingkat daerah, arah kebijakan kewilayahan RPJMD secara eksplisit tidak mencantumkan pembangunan perbatasan sebagai suatu tema khusus. Namun, masalah-masalah pembangunan di wilayah perbatasan antar negara telah diidentifikasi mulai dari batas administrasi, hukum, pertahanan dan keamanan, kesejahteraan masyarakat, hingga sinergi kebijakan. Dengan demikian, arah kebijakan pembangunan kawasan perbatasan dilebur ke dalam bidang-bidang sasaran berdasarkan misi pembangunan. Arah kebijakan ini dijabarkan ke dalam perencanaan tahunan dengan strategi mengurangi desa tertinggal dan desa sangat tertinggal di kawasan perbatasan (BAPPEDA, 2021)

\section{c. Peran Perbankan dalam Pembangunan Kawasan Perbatasan}

Berdasarkan Undang-Undang Nomor 7 Tahun 1992 tentang Perbankan, Bank adalah badan usaha yang menghimpun dana dari masyarakat dalam bentuk simpanan dan menyalurkannya kepada masyarakat dalam bentuk kredit dan atau bentuk-bentuk lainnya dalam rangka meningkatkan taraf hidup rakyat banyak. Selanjutnya Undangundang tersebut juga menyebutkan fungsi perbankan sebagai penghimpun dan penyalur dana masyarakat, serta tujuan perbankan yaitu menunjang pelaksanaan pembangunan nasional dalam rangka meningkatkan pemerataan, pertumbuhan ekonomi, dan stabilitas nasional ke arah peningkatan kesejahteraan rakyat banyak. Dari pengertian, fungsi dan tujuan perbankan tersebut, dapat terlihat peran strategis lembaga keuangan perbankan dalam mendukung pencapaian tujuan pembangunan nasional.

Dalam pembangunan ekonomi, keberadaan bank sangat diperlukan untuk menyalurkan dana sebagai modal usaha mikro, usaha kecil, dan usaha menengah sehingga mampu menggerakkan perekonomian masyarakat pada sektor riil. Dengan bergeraknya perekonomian 
masyarakat, maka akselerasi pembangunan nasional juga akan terwujud (Fahrial, 2018).

Dalam konteks pembangunan daerah, salah satu tolok ukur pembangunan daerah adalah kemandirian daerah yang seringkali ditunjukkan dengan indikator proporsi Pendapatan Asli Daerah (PAD) dalam Anggaran Pendapatan dan Belanja Daerah (APBD). Semakin tinggi proporsi PAD dalam APBD, maka semakin mandiri daerah tersebut. Bagi Kalimantan Barat yang memiliki wilayah perbatasan antar negara, tentulah aspek kemandirian daerah ini sangat berkaitan dengan tuntutan percepatan pengentasan kawasan perbatasan dari ketertinggalan.

Upaya pembangunan kawasan perbatasan dengan mengedepankan pendekatan kesejahteraan tentunya akan menitikberatkan pada pembangunan ekonomi. Semakin meningkatnya pembangunan ekonomi di kawasan perbatasan akan berakibat pada penciptaan lapangan kerja dan selanjutnya akan membentuk distribusi pendapatan di kalangan masyarakat.

Lembaga keuangan perbankan diakui memiliki peran penting dalam menghimpun dan menyalurkan dana masyarakat, khususnya sebagai modal usaha mikro, usaha kecil dan usaha menengah. Majunya usaha masyarakat setidaknya akan berdampak pada meningkatnya pendapatan dan terciptanya peluang kerja. Meningkatnya pendapatan selain berakibat pada peningkatan kesejahteraan masyarakat, juga akan membawa dampak peningkatan tabungan masyarakat. Kesejahteraan yang meningkat membuat masyarakat memiliki kelebihan dana setelah penggunaannya untuk konsumsi (Kornita \& Mayes, 2010). Oleh karena itu, Bank juga akan mendapatkan kesempatan yang lebih baik dalam menghimpun dana masyarakat.

Di sisi lain, meningkatnya kontribusi Perbankan terhadap PAD akan meningkatkan kemampuan daerah dalam pembiayaan pembangunan. Dalam hal ini, Pemerintah Daerah akan dapat meningkatkan layanan infrastruktur ekonomi dan sosial, kesejahteraan masyarakat, penjagaan keamanan dan pemeliharaan ketenteraman dan ketertiban di kawasan perbatasan. Peningkatan hasil-hasil pembangunan berkat meningkatnya PAD pada gilirannya juga akan semakin memperkuat kinerja perekonomian di kawasan tersebut.

Berdasarkan Akta Pendirian Perseroan Terbatas Perubahan Terakhir Tahun 2019, orientasi pelayanan Bank Kalbar adalah pada penghimpunan dana masyarakat dan menyalurkannya kembali dalam bentuk kredit dan pembiayaan, serta memberikan layanan jasa perbankan lainnya baik secara konvensional maupun berdasarkan prinsip syariah (BANK KALBAR, 2020). Rumusan karakteristik Bank Kalbar di atas menunjukkan serupanya bisnis Bank Kalbar dengan bank-bank lainnya. Namun, terdapat beberapa karakteristik khusus yang menjadi kelebihan Bank Kalbar, yaitu kepemilikan saham yang $100 \%$ adalah Pemerintah Daerah Provinsi dan Pemerintah daerah Kabupaten/Kota se-Kalimantan Barat, fungsi Bank Kalbar sebagai pemegang Kas daerah, serta fungsinya sebagai sumber Pendapatan Asli Daerah.

Untuk menyebarluaskan layanannya, Bank Kalbar memiliki jaringan pelayanan yang tersebar mulai dari Kantor Pusat di Pontianak, hingga bentuk-bentuk pelayanan yang lebih kecil (ATM, CDM dan CRM). Dari sebaran lokasi, layanan Bank Kalbar juga tersebar di seluruh Kabupaten/Kota dan telah pula memiliki Kantor Cabang di Jakarta

Tabel 1. Jaringan Pelayanan Bank Kalbar Tahun 2020

\begin{tabular}{|l|l|l|}
\hline No. & \multicolumn{1}{|c|}{ JENIS } & JUMLAH \\
\hline 1. & Kantor Pusat Syariah & 1 \\
\hline 2. & $\begin{array}{l}\text { Unit Usaha Cabang } \\
\text { Umum }\end{array}$ & 19 \\
\hline 3. & $\begin{array}{l}\text { Kantor } \\
\text { Konvensional }\end{array}$ & 4 \\
\hline 4. & Kantor Cabang Syariah & $\begin{array}{l}\text { Kantor Cabang pembantu } \\
\text { Konvensional }\end{array}$ \\
\hline 5. & $\begin{array}{l}\text { Kantor Cabang pembantu } \\
\text { Syariah }\end{array}$ & 1 \\
\hline
\end{tabular}




\begin{tabular}{|l|l|l|}
\hline No. & \multicolumn{1}{|c|}{ JENIS } & JUMLAH \\
\hline 7. & Kas Mobil Konvensional & 60 \\
\hline 8. & Kantor Kas Syariah & 6 \\
\hline 9. & Kas Mobil Konvensional & 14 \\
\hline 10. & Kas Mobil Syariah & 1 \\
\hline 11. & Payment Point & 71 \\
\hline 12. & Layanan Syariah & 65 \\
\hline 13. & ATM Bank Kalbar & 258 \\
\hline 14. & CDM bank Kalbar & 16 \\
\hline 15. & CRM Bank Kalbar & 4 \\
\hline
\end{tabular}

Sumber: Laporan Tahunan Bank Kalbar Tahun 2020

\section{d. Model Peningkatan Layanan Digital Perbankan}

Kegiatan perekonomian wilayah, termasuk di dalamnya kawasan perbatasan merupakan buah interaksi antara sektor riil dan sektor moneter. Interaksi kedua sektor ini bersifat saling mempengaruhi. Kinerja sektor riil akan mempengaruhi kinerja sektor moneter, begitu pula sebaliknya (Kornita \& Mayes, 2010).

Kemampuan Bank Kalbar dalam menghimpun dan menyalurkan dana masyarakat akan sangat menunjang kelancaran perekonomian sektor riil di kawasan perbatasan. Semakin meningkat peran Bank Kalbar dalam perekonomian wilayah perbatasan, semakin lancar pula kegiatan investasi-distribusi-dan konsumsi di kawasan tersebut.

Dalam rangka meningkatkan kinerja pelayanan, Bank Kalbar perlu memahami preferensi dari pelanggannya. Preferensi ini terbentuk dari kepuasan dan loyalitas pelanggan (Mbama \& Ezepue, 2018). Pengalaman pelanggan terbentuk dari interaksi antara pelanggan, produk dan perusahaan. Dalam hal ini, pelanggan akan membandingkan apa yang mereka dapatkan secara aktual dari pelayanan dengan harapan mereka akan pelayanan tersebut. Apabila pelanggan merasakan kepuasan atas layanan, maka terbentuklah loyalitas terhadap produk dan perusahaan.

Meskipun Bank Kalbar dikenal dengan image sebagai bank daerah, namun belum tentu menjadi leader dalam bisnis perbankan di daerah. Oleh karena itu, menjadi sangat penting bagi Bank Kalbar untuk meningkatkan kinerjanya dengan menitikberatkan pada pembentukan pengalaman yang positif bagi pelanggan dalam mendapatkan pelayanan. Pembentukan pengalaman ini dimodelkan oleh Vebiana (2018) dengan memperhitungkan variabel-variabel kenyamanan; kualitas fungsional; kualitas layanan; merek/kepercayaan; employee customer engagement; dan inovasi perbankan digital.

Di dalam Laporan Tahunan Bank Kalbar Tahun 2020, disebutkan bahwa salah satu kelebihan dari perusahaan adalah adanya nasabah yang loyal dari kalangan pegawai negeri sipil (ASN) dan para pensiunan. Hal ini memang merupakan suatu kekuatan Bank Kalbar yang tidak dimiliki oleh bank lain. Namun, perlu dipertimbangkan pula alasan keikutsertaan ASN sebagai nasabah yang secara by system pengelolaan rekening gajinya dilakukan oleh Bank Kalbar. Sangat memungkinkan jika untuk keperluan lainnya para ASN mempercayakan kepada bank lain. Dengan demikian, Bank Kalbar tentunya perlu untuk semakin memperkuat posisinya dalam pelayanan kepada masyarakat umum, khususnya pelaku usaha yang notabene mayoritas dilakukan oleh aktor-aktor non Pemerintah atau aparatur pemerintah. Untuk itu, kebijakan perencanaan dan pelayanan Bank Kalbar juga hendaknya dapat membentuk image baru sebagai bank untuk semua kalangan sehingga semakin membuka kesempatan dan meningkatkan preferensi masyarakat non ASN untuk menjadi nasabah dan mendapatkan pelayanan jasa keuangan dari Bank Kalbar.

Brand image dipercaya memiliki dampak yang positif terhadap loyalitas, komitmen, persepsi terhadap kualitas, serta kepuasan. Selain itu, juga berperan dalam membangun loyalitas dan kepuasan bagi mereka yang menjadi pelanggan baru (Keisidou, Sarigiannidis, \& Maditinos, 2013). Image Bank Kalbar sebagai bank pelat merah tentunya akan membentuk persepsi dalam masyarakat bahwa kinerja Bank Kalbar tak berubahnya kinerja 
birokrasi yang dipandang kurang memuaskan, tidak terintegrasi secara online, tidak inovatif, serta ditangani aparatur yang kurang berkompeten (Hidayat, 2019). Apalagi diperkuat fakta bahwa bank ini 100\% sahamnya dimiliki oleh Pemerintah Daerah serta berfungsi sebagai pemegang Kas Daerah dan sumber Pendapatan Asli Daerah (PAD). Untuk itu, Bank Kalbar perlu mempromosikan peningkatan kinerja pelayanan yang setara dengan bank umum lainnya dan mempertimbangkan untuk melakukan rebranding sebagai bank untuk semua. Dengan brand image yang baru, maka Bank Kalbar juga diharapkan dapat menjaring nasabah-nasabah baru, membentuk persepsi kepuasan atas pelayanan dan membangun loyalitas.

Tema pelayanan yang diusung oleh Bank Kalbar pada tahun 2020 adalah Sinergi Bersama Dukung Percepatan Ekonomi melalui Digitalisasi (BANK KALBAR, 2020). Melalui tema ini, Bank Kalbar menyadari peran pentingnya dalam menggerakkan perekonomian Kalimantan Barat. Selain itu, semakin ketaatnya persaingan menuntut peningkatan kualitas pelayanan yang mampu memenuhi tuntutan masyarakat akan pelayanan yang cepat, tepat dan murah. Untuk itu, Bank Kalbar dituntut mampu untuk terus melakukan inovasi pelayanan dan mengembangkan fitur-fitur layanan perbankan melalui digitalisasi.

Sejalan dengan tema Sinergi Bersama Dukung Percepatan Ekonomi melalui Digitalisasi, Bank Kalbar telah meluncurkan fitur digital seperti mobile banking dan SMS Notifikasi (BANK KALBAR, 2020). Pemanfaatan mobile banking telah pula mewujudkan pelayanan yang mudah dalam satu genggaman, di mana berbagai keperluan transaksi dapat dipenuhi hanya dengan menggunakan perangkat telepon cerdas (smartphone). Platform yang tersedia ini kiranya dapat diperluas fitur layanannya sehingga secara fungsional dapat benarbenar memenuhi kebutuhan masyarakat.

Penggunaan teknologi digital dalam jasa keuangan perbankan sangat ditentukan oleh kepuasan masyarakat pengguna terhadap kualitas fungsional dari sistem pelayanan online. Bank Kalbar perlu memperhatikan perilaku pengguna layanan digital bankingnya untuk mengetahui celah pelayanan yang semestinya ditutup demi membentuk pengalaman positif dan kepuasan para nasabah. Sebagai contoh, trend belanja secara online yang benar-benar mengandalkan kecepatan dan kemudahan dalam transaksi perdagangan.

Aktivitas perdagangan di kawasan perbatasan kiranya tidak steril dari model perdagangan online. Meningkatnya trend belanja online kiranya perlu mendapatkan perhatian dalam upaya pengembangan layanan. Pada umumnya bank-bank yang telah bekerja sama dengan marketplace belanja online adalah bank-bank swasta nasional. Bagi nasabah bank yang bekerja sama dengan marketplace tidak dibebani dengan biaya transfer. Hal ini tentu saja menjadi salah satu pengikat loyalitas nasabah.

Terkait dengan pengaruh digitalisasi perbankan terhadap kinerja keuangan bank, Mbama and Ezepue (2018) mengembangkan model yang menggambarkan hubungan antara pengalaman pelanggan, kepuasan pelanggan, loyalitas pelanggan dan kinerja bank. Hubungan tersebut digambarkan dalam model sebagai berikut:

Gambar 1: Model Hubungan Pengalaman Pelanggan dan Kinerja Bank

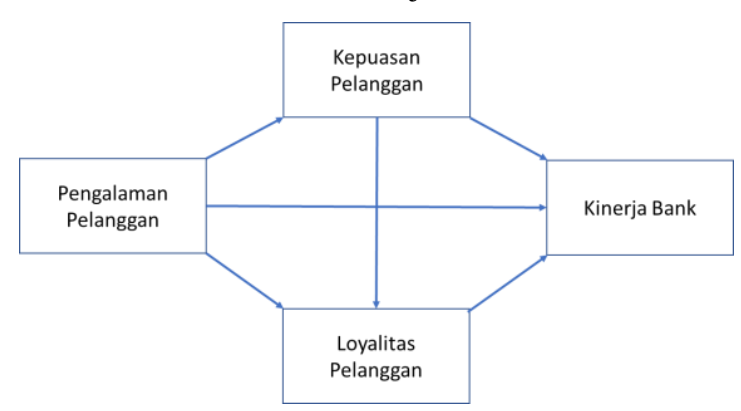

Sumber: Mbama and Ezepue (2018)

Dari bagan model tersebut, pengalaman pelanggan dibentuk oleh dimensi-dimensi nilai yang dirasakan; kenyamanan; kualitas fungsional, kualitas pelayanan; merk; pelayanan pelanggan; persepsi resiko; persepsi manfaat; dan inovasi perbankan. 
Terkait dengan peningkatan peran Bank Kalbar sebagai lembaga keuangan dalam pembangunan kawasan perbatasan di era digital, dapat disusun suatu model dengan mengadopsi model di atas, dengan menitikberatkan pada penguatan inovasi, mempertimbangkan rebranding dan penguatan sinergi dengan Pemda dan stakeholder terkait. Berdasarkan hal tersebut, maka diajukan model sebagai berikut:

\section{GAMBAR 2: MODEL PENINGKATAN PERAN BANK KALBAR DALAM PEMBANGUNAN PERBATASAN.}

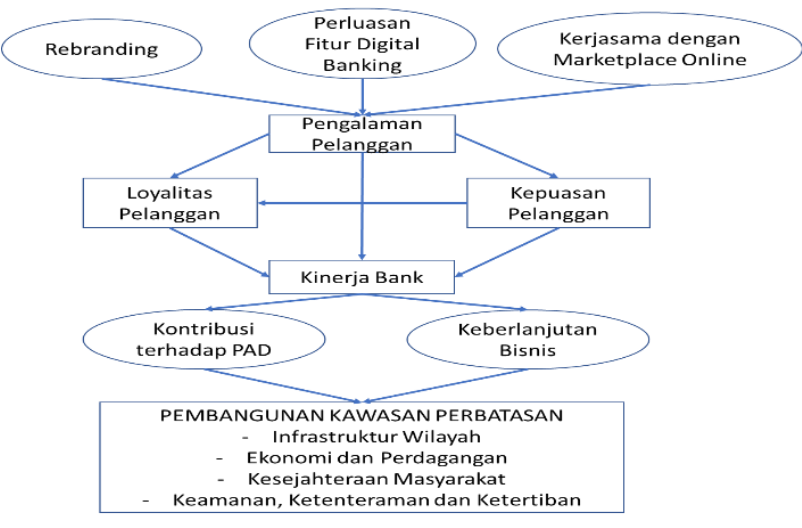

Pada gambar di atas, Penulis menambahkan beberapa hal yang perlu dilakukan guna memperkuat aspek pengalaman pelanggan terhadap layanan bank. Pertama, rebranding yang diarahkan untuk memperkuat brand image sebagai bank untuk semua atau sesuai tagline Bank Kalbar: "Bank Kite Punye Kite". Hal ini dimaksudkan agar masyarakat tidak beranggapan bahwa Bank Kalbar umpamanya sebagai lembaga pemerintah. Brand (merk) yang dibangun oleh Bank Kalbar hendaknya berorientasi kepada konsumen, sehingga mampu membuat mereka merasakan kepuasan dari produk yang dipasarkan dan mempertahankan hubungan dengan perusahaan (Haryanto \& Dewi, 2020).

Berbagai penelitian menunjukkan bahwa pemasaran secara digital saat ini memiliki pengaruh yang signifikan terhadap kinerja pemasaran perbankan. Dengan demikian, perbankan perlu memperhatikan ketepatan target, ketepatan promosi produk dan penguatan manajemen organisasi. (Haryanto \& Dewi, 2020)

Kedua, perluasan fitur digital banking yang akan memperkuat kualitas fungsional dari layanan digital. Hal ini diharapkan benar-benar dapat mewujudkan tujuan digital banking yang menempatkan semua layanan dalam satu genggaman. Dengan adanya digital banking memungkinkan konsumen untuk mengakses layanan perbankan 24 jam. Dengan demikian akan semakin menaik minat dan membangun kepercayaan nasabah. Produk-produk perbankan mungkin saja tidak berbeda jauh, namun peningkatan kualitas pelayanan yang akan menentukan (Marlina \& Humairah, 2018).

Ketiga, membangun kerja sama dengan marketplace online yang saat ini lebih banyak dijalin oleh bank swasta nasional. Terkait dengan aktivitas perdagangan di kawasan perbatasan, sesungguhnya pembeli di platform online banyak yang bukan lagi merupakan end user, namun pedagang perantara yang juga berpotensi melakukan aktivitas perdagangan internasional di kawasan perbatasan.

Trend pertumbuhan perdagangan online di Kalimantan Barat menunjukkan besarnya peluang pertumbuhan dan perkembangan ekonomi digital serta pengaruhnya terhadap aktivitas ekonomi masyarakat secara keseluruhan. Oleh karena itu, perbankan dapat mendukung upaya penetrasi pemanfaatan marketplace serta meningkatkan literasi masyarakat melalui pembangunan peta jalan yang membuka akses berbagai sektor untuk bergabung dan memperkuat ekosistem perdagangan digital di Kalimantan Barat (Al Rizki, Bustaman, \& Pramana, 2020).

Peningkatan kinerja Bank selain dalam rangka mempertahankan keberlangsungan bisnis, juga diharapkan dapat meningkatkan kontribusi terhadap PAD. Dari aspek keberlangsungan bisnis, Bank Kalbar diharapkan dapat meningkatkan layanan jasa keuangan guna menunjang kegiatan ekonomi dan perdagangan, serta menyediakan dukungan finansial bagi 
proyek-proyek pembangunan. Sebagai suatu Badan Usaha Milik Daerah, kontribusi Bank Kalbar dalam PAD adalah bagian dari laba atas penyertaan modal yang dilakukan oleh Pemerintah Daerah (berdasarkan Peraturan Menteri Dalam Negeri Nomor 21 Tahun 2011 tentang Perubahan Kedua atas Peraturan Menteri Dalam Negeri Nomor 13 Tahun 2006 tentang Pedoman Pengelolaan Keuangan Negara). Dengan demikian, dari aspek kontribusi terhadap PAD jelas merupakan bagian dari peran strategis Bank Kalbar sebagai lembaga jasa keuangan milik Daerah yang dibentuk guna menunjang upaya Pemerintah Daerah dalam membangun kesejahteraan masyarakat dan kemajuan daerah.

\section{KESIMPULAN}

Pemanfaatan teknologi digital dalam memberikan pelayanan kepada masyarakat sudah menjadi keharusan dalam rangka memenuhi kebutuhan dan harapan masyarakat. Meskipun kawasan perbatasan sering dikategorikan sebagai kawasan yang tertinggal, namun menyimpan peran strategis dalam perdagangan dan kegiatan ekonomi lainnya bagi ketercapaian tujuan pembangunan daerah.

Seiring dengan arus digitalisasi pelayanan, Bank Kalbar juga telah menetapkan tema-tema laporan tahunan yang menitikberatkan pada digitalisasi pelayanan. Terkait dengan hal tersebut, dalam rangka mengoptimalkan pengalaman positif nasabah sehingga membentuk kepuasan terhadap layanan Bank Kalbar, maka diajukan model peningkatan peran Bank Kalbar dalam pembangunan kawasan perbatasan. Model tersebut menggambarkan bagaimana meningkatkan peran Bank Kalbar dalam pembangunan kawasan perbatasan. Pada aspek pengalaman pelanggan, diusulkan upaya rebranding, perluasan fitur layanan digital, serta kerja sama dengan marketplace online dalam rangka memberikan pelayanan terbaik kepada masyarakat di era digital ini. Hal ini lah yang akan memicu peningkatan kinerja bank, khususnya dalam menghasilkan PAD bagi daerah dan mempertahankan keberlangsungan pelayanannya. Dengan kinerja yang baik, peluang Bank Kalbar untuk meningkatkan perannya dalam pembangunan perbatasan juga semakin besar.

\section{UCAPAN TERIMA KASIH}

Sepanjang penulisan makalah in, Penulis mendapatkan banyak support dan bantuan dari berbagai pihak, termasuk Direktur Bank Kalbar yang telah memberikan informasi yang sangat penting terkait kiprah Bank Kalbar dewasa ini.

\section{DAFTAR PUSTAKA}

Al Rizki, D., Bustaman, U., \& Pramana, S. (2020). Pemanfaatan Big data Marketplace terhadap Profil Ekonomi Digital Daerah Sektor Perdagangan di Kalimantan Barat. Seminar Nasional Official Statistics 2020: Statistics in New Normal: A Challenge of Big Data and Official Statistics, (pp. 695-703).

BANK KALBAR. (2020). Sinergi Bersama Dukung Percepatan Ekonomi melalui Digitalisasi : Laporan Tahunan. Pontianak.

BAPPEDA, B. P. (2021). Akselerasi Pembangunan Ekonomi Inklusif Berbasis SDA dan Peningkatan SDM yang Berkualitas . Forum OPD Pengelolaan Perbatasan. Pontianak.

BNPP, B. N. (2011). Desain Besar Pengelolaan Batas Wlayah Negara dan Kawasan Perbatasan di Indonesia Tahun 2011-2025. Jakarta.

BPPD, B. P. (2021, August 20). Data Umum Pembangunan Kawasan Perbatasan Kalimantan Barat. Retrieved from Badan Pengelola Perbatasan Daerah: bppd.kalbarprov.go.id

Fahrial. (2018). Peranan Bank dalam Pembangunan Ekonomi Nasional. Ensiklopedia of Journal, 1(1), 179184. 
Haryanto, A., \& Dewi, S. (2020). Strategi Pengembangan Digital Marketing, Orientasi Ekuitas Merk, Merketing Intermediaris dan Kinerja Pemasaran di Perbankan Syariah. Jurnal Ilmiah Ekonomi Islam, 6(2), !63-170.

Hendri, M., \& Hasanuddin. (2017). Model Pengembangan Minat dan Kemampuan Berwirausaha Generasi Muda dengan Memanfaatkan Potensi Ekonomi Wilayah Perbatasan di kabupaten Sambas. Entrepreneurship at Global Crossroad: Challenges and Solutions (pp. 684-693). Tangerang Selatan: Universitas Terbuka.

Hidayat, E. (2019). Kinerja Pelayanan Birokrasi dalam Mewujudkan Kepuasan Pelanggan. Dinamika, 6(2), 43-49.

Keisidou, E., Sarigiannidis, L., \& Maditinos, D. (2013). Customer satisfaction, loyalty and financial performance: A holistic approach of the Greek banking sector. International Journal of Bank Marketing, 3(4), 259-288.

Kemitraan. (2011). Kebijakan Pengelolaan Kawasan Perbatasan Indonesia. Kemitraan Partnership. Jakarta: Kemitraan Partnership.

Kornita, S., \& Mayes, A. (2010). Analisis Peran Perbankan dalam Perekonomian di Kabupaten Siak. Jurnal Ekonomi, 18(1), 50-65.

Kurniadi, D. (2009). Strategi Pengembangan Wilayah Perbatasan Antar Negara : Memacu Pertumbuhan Ekonomi Entikong Kabupaten Sanggau Provinsi Kalimantan Barat (THESIS). Semarang: Universitas Diponegoro.
Marlina, A., \& Humairah, F. (2018). Peran Digital Banking dalam Meningkatkan Kepuasan Nasabah Kredit (Studi Kasus PT. Bank Tabungan Negara Syariah). MONETER Jurnal Keuangan dan Perbankan, 6(2), 37-44.

Mbama, C., \& Ezepue, P. (2018). Digital Banking, Customer Experience and Bank Financial Performance: UK Customer's Perceptions. International Journal of bank marketing, 36, 230-255.

Sudiar, S. (2015). Pembangunan Wilayah Perbatasan Negara: Gambaran Tentang Strategi Pengelolaan Kawasan Perbatasan Darat di Provinsi Kalimantan Utara. Jurnal Administrative Reform, 3(4), 489500.

van Houtum, H. (2005). The Geopolitics of Border and Boundaries. Geopolitics, 10, 672-679.

Vebiana, V. (2018). Perbankan Digital, Pengalaman Pelanggan, dan Kinerja Keuangan bank Syariah. 9th Industrial Research Workshop and National Seminar, (pp. 747-751).

Wiwoho, J. (2014). Peran Lembaga Keuangan Bank Dan Lembaga Keuangan Bukan Bank Dalam Memberikan Distribusi Keadilan Bagi Masyarakat. Jurnal MMH Universitas Diponegoro, 43, 87-97.

YIN, R. (2006). Case Study Research: Design and Methods. Applied Social Research Methods. London: Sage. 
Bidang Ilmu Pengetahuan Sosial 